\title{
Cranial Trauma and Crime at Harappa
}

\section{Anek R Sankhyan*}

Senior Anthropologist (Physical) \& Visiting Fellow, Anthropological Survey of India (rtd.), President Palaeo Research Society, India

Submission: December 20, 2017; Published: January 08, 2018

*Corresponding author: Anek R Sankhyan, Senior Anthropologist (Physical) \& Visiting Fellow, Anthropological Survey of India (rtd.), President Palaeo Research Society, India, Email: arsankhyan@gmail.com

\section{Short Communication}

This brief communication re-looks at some of the cases of cranial trauma in Harappan skeletons, earlier interpreted in terms of inter-personal violence and social stratification by us [1]. The Anthropological Survey of India in its Head Office at Kolkata houses a huge repository of the ancient skeletal remains in the Palaeoanthropology Section, under the Charge of the author for two decades. Of this repository, the author had studied two cases of trepanations in details, one from the Neolithic Burzahom, Kashmir [2-4] and another from the Bronze Age Harappa [5]. Both of these individuals suffered from cranial trauma and were treated medically through trepanation. But, why these traumas occurred has not been examined from criminal investigation point of view. The Harappan skeletal repository contains 160 skeletons catalogued by Gupta et al. [6].
Among these, nine individuals suffered from craniofacial trauma; two were immature individuals, four adult females, and three adult males [1]. Among these only two victims - one adult male and one adult female were from Cemetery R-37, which is the most advanced and urbanized cemetery. We had categorized the traumatic lesions into five types:

a) Injuries to the upper and lower portions of the cranial vault consistent with forceful blows from a long, club-like weapon,

b) Circular depression fractures on the frontal squama, near bregma,

c) Sharp blunt force trauma to the facial skeleton,

d) Broken noses, and

e) Lesions suggestive of trepanation.

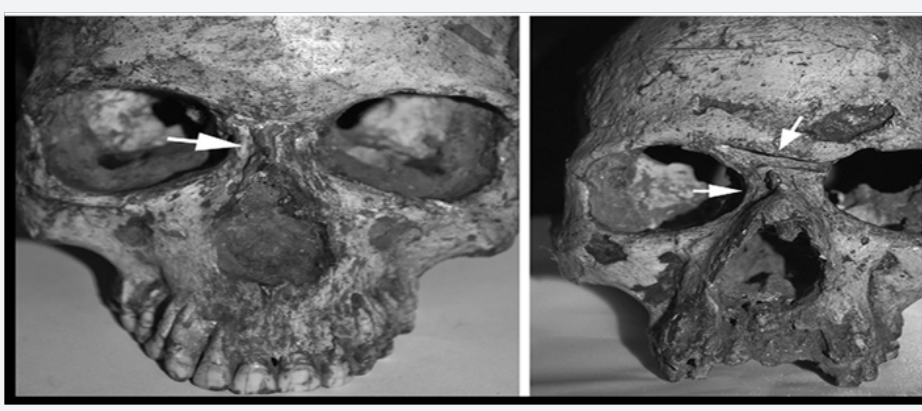

Figure 1: A sharp nasal trauma (Area G).

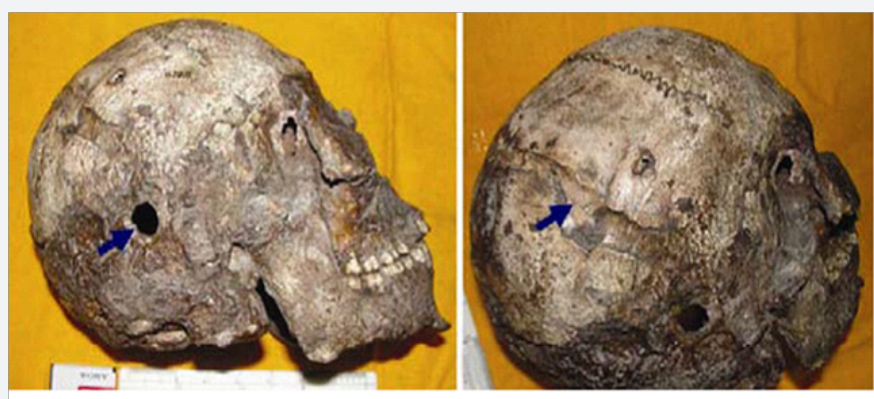

Figure 2: A big horizontal trauma marked by arrow and a trepanned hole (796/B: R37). 
We had concluded that the more traumatic injuries occurred in the Area G of the post-urban period burials, where injuries also included healed broken noses and blunt force trauma at glabella in males; all traumas were attributed to violence and none to accidents. These traumas indicate greater violence and prevalence of crimes in Area G. The Urban Cemetery R-37, however, showed minimum violent trauma in two individuals treated by trepanation, an ancient medical intervention to deal with symptoms related to trauma and pathology. One Harappan skull (H 796/B) of Cemetery in Square R-37 showed clear evidence of trepanation. The Cemetery is located on slightly raised ground to the south of the preserved fractional burial with the head turned on the cheek and the skeleton in burial oriented in N-S direction. Gupta et al. [6] had not recognized the trepanation which was first thought by Roy Chowdhury [7] who made a mention without the image of the trepanned skull. It was only in 2011 that the author illustrated the case of trepanation at Harappa $[4,5]$. This trepanned skull is of an adult male of $\sim 30$ years of age, sub-mesocranic category with the LBI $=75.84$ and high $(1336.67 \mathrm{cc})$ cranial capacity. The skull has two depression fractures on the right parietal. A fracture superior to and running parallel with the temporal line caused plastic deformation and upheaval of the bone from the coronal suture to the parietal eminence. A second fracture runs perpendicular to the first, from the sagittal to the squamous suture. This fracture leaves a depression $\sim 50 \mathrm{~mm}$ in length and $20 \mathrm{~mm}$ in breadth (Figures $1 \& 2$ ).

This fracture caused a linear depression with cracked margins visible on the parietals. It is not an accidental trauma but very likely resulted from a severe blow using a strong wooden club. The position of the trauma indicates that the victim has been attacked from behind and the side to kill, apparently without challenging. The enemy/criminal might have escaped or captured and punished later, but the victim was given a medical treatment in the form of trepanation as a prevalent surgical operation to remove the bone splinters and blood clotting or hematoma and clean the wound. This is indicated by a round hole (5 $\mathrm{mm}$ in diameter) near asterion [5]. There is little evidence of healing or remodeling around either of these lesions, which also indicates that the victim could not survive long after the trauma. How long he survived the operation could be indicated by sclerosis by imaging the rim and the internal compact bone using Computed Tomography. Forensic anthropologists should investigate the ancient traumas from criminal points of view.

\section{References}

1. Robbins Schug G, Gray K, Mushrif Tripathy V, Sankhyan AR (2012) A peaceful realm? Trauma and social differentiation at Harappa. International Journal of Paleopathology 2: 136-147.

2. Sankhyan AR, Weber GHJ (2001) Evidence of surgery in Ancient India: Trepanation at Burzahom (Kashmir) over 4000 years ago. International Journal of Osteoarchaeology 11(5): 375-380.

3. Sankhyan AR (2008) Surgery in ancient India. In H Selin (Edn), Encyclopedia of the history of science, technology, and medicine in non-western cultures, UK, pp. 2060-2063.

4. Sankhyan AR (2015) Surgery in Ancient India. Encyclopaedia of the History of Science, Technology, and Medicine in Non Western Cultures p. 1-9.

5. Sankhyan AR, Robbins Schug G (2011) First evidence of brain surgery in Bronze Age Harappa. Current Science 100 (11): 1621-1622.

6. Gupta P, Dutta PC, Basu A (1962) Human skeletal remains from Harappa. Anthropological Survey of India, Calcutta, India, p. 1-9.

7. Roy Chowdhury AK (1973) Trepanation in ancient India. Journal of the Asiatic Society of Bengal 15: 203-204.

Your next submission with Juniper Publishers will reach you the below assets

- Quality Editorial service

- Swift Peer Review

- Reprints availability

- E-prints Service

- Manuscript Podcast for convenient understanding

- Global attainment for your research

- Manuscript accessibility in different formats

( Pdf, E-pub, Full Text, Audio)

- Unceasing customer service

Track the below URL for one-step submission https://juniperpublishers.com/online-submission.php 